\title{
ANATOMICAL VARIATIONS IN THE HUMAN SINUATRIAL NODAL ARTERY
}

\author{
José Roberto Ortale, Cristiane de Freitas Paganoti, Gabriel Franceschi \\ Marchiori
}

Ortale JR, Paganoti C de F, Marchiori GF. Anatomical variations in the human sinuatrial nodal artery. Clinics. 2006;61(6): 551-8.

OBJECTIVE: To analyze the anatomical variations of sinuatrial nodal branch(es) of the coronary artery mainly regarding their number; a recent report from Japan claims the presence of 2 branches in up to $50 \%$ of cases, an occurrence that would permit adequate flow compensation in case of occlusion or section of 1 of these branches.

METHODS: The sinuatrial nodal branch(es) of 50 human hearts fixed in formol solution were dissected with the aid of a Normo Health 3.0 degree visor magnifying lens, measured, and classified as to the origin, route, and number of branches.

RESULTS: In 94\% ( $\mathrm{n}=47$ ) of cases, a single sinuatrial nodal branch was found. classified: (A) two right side types, R1 (in $46 \%$ of cases, $n=23$ ), situated medial to the right auricle and R2 (in $4 \%$ of cases, $n=2$ ), situated on the posterior surface of the right atrium; (B) three left side types, L1 (in $24 \%$ of cases, $n=12$ ), situated medial to the left auricle, L2 (in $16 \%$ of cases, $n=8$ ), situated posterior to the left auricle, and L3 (in $4 \%$ of cases, $n=2$ ), situated on the posterior surface of the left atrium. Except for $\mathrm{R} 2$, each type was subdivided into ' $a$ ' or ' $b$ ' types, according to whether the sinuatrial nodal branch(es) occurred in a clockwise or counterclockwise orientation around the base of the superior cava vena. In $4 \%$ of cases $(n=2), 2$ sinuatrial nodal branch(es) were observed with 1 branch originating from each of the coronary arteries. In 1 case (2\%), 3 sinuatrial nodal branch(es) were found, 2 from the right coronary artery and the third probably from the bronchial branch of the thoracic aorta. In $30 \%$ of the cases, the sinuatrial nodal branch(es) formed a ring around the base of the superior cava vena. In all cases, the sinuatrial nodal branch(es) supplied collateral branches to the atrium and/or the auricle of the same side as its origin and/or to the opposite side.

CONCLUSION: The low frequency of 2 sinuatrial nodal branch(es) in Brazilian individuals, compared to the higher frequency found among the Japanese, is probably due to a variation associated with ethnic group origin.

KEYWORDS: Arteries. Coronary circulation. Atrium. Cardiac conduction system. Macroscopic anatomy. Sinuatrial nodal artery.

\section{INTRODUCTION}

Besides being an excellent guide to the location of the sinuatrial node, detailed anatomical knowledge of the blood supply to the sinuatrial node region, an investigated topic, demands further study due to its application in cardiac surgery and in cardiology, in order to more clearly understand disturbances in its function caused by coronary disease..$^{1-7}$

Disciplina de Anatomia, Faculdade de Ciências Biológicas - Centro de Ciências da Vida, Pontifícia Universidade Católica de Campinas - Campinas/ SP, Brasil

Email: ortalejr@uol.com.br

Received for publication on March 03, 2006.

Accepted for publication on August 11, 2006.
In the last decade, with the advent of new surgical techniques used in the treatment of arrhythmias, more specifically of atrial fibrillation, knowledge of the characteristics and trajectory of the atrial branches, particularly the sinuatrial nodal branches of the coronary artery (SANB), have assumed great importance..$^{8-11}$

With respect to the origin of arterial irrigation to the sinuatrial node, some authors have described it as a single branch, originating from the right coronary artery, from the circumflex branch of the left coronary artery and/or from the trunk of the left coronary artery, ${ }^{1,2,5,7,9,12-14}$ or even of the left bronchial artery. ${ }^{15}$ Other authors have reported the possible presence of 2 branches in up to $11 \%$ of cases. . $^{3,4,8,16-18}$ Recently, Futami et $\mathrm{al}^{10}$ and Kawashima and Sasaki ${ }^{11}$ found 
several branches at much higher frequencies-in up to $54 \%$ of cases among Japanese individuals.

Due to the variations found in the literature, we decided to investigate the anatomy of arterial irrigation to the sinuatrial node region regarding the origin, route, and number of branches, with the aim of contributing to the detailed knowledge applied to atrial arrhythmia diagnosis and atrial surgical intervention.

\section{MATERIALS AND METHODS}

The 50 human adult hearts studied in the present investigation, obtained from the Instituto de Medicina Legal de Campinas were fixed in $10 \%$ formol solution, preserved in $5 \%$ formol solution, and belong to the series used by Ortale $^{19,20}$ in his description of the branches of the coronary arteries. The dissection was authorized by the Centro de Ciências da Vida, Pontifícia Universidade Católica de Campinas, as part of an approved project.

After removal of the epicardium, the surface branching of the left and right coronary arteries was dissected. To dissect the SANB, a Normo Health Care NH-01 3.0 dioptrics (degree) visor magnifying lens was used.

The length and diameter of each SANB was measured, together with its origin and in which sinuatrial node region it was positioned. Each SANB was classified as follows: left or right $(\mathrm{L} / \mathrm{R})$ types, according to its respective origin from the left/right coronary artery; subtypes L1/L2/L3, according to its respective route medial/posterior to the left auricle or on the posterior surface of the left atrium; and R1/R2, according to its respective route medial to the right auricle or on the posterior surface of the right atrium., ${ }^{5,9}$ The latter subtypes were classified into $a$ or $b$ type, according to its respective orientation, clockwise or counter-clockwise, and analyzed for the possibility of complete/incomplete ring formation around the base of the superior vena cava. ${ }^{2}$

Accordingly, each SANB, except for the branch of probable bronchial artery origin, was classified into one of the following types (Figure 1):

$\mathrm{R} 1$ originating in the right coronary artery with a route medial to the right auricle, and subdivided into R1a (Figure 2) and $\mathrm{R} 1 b$, according to its clockwise or counterclockwise route, respectively, in the sinuatrial node region at the base of the superior vena cava.

$\mathrm{R} 2$ originating in the right coronary artery with a route that traversed the posterior surface of the right atrium, crossing the sinuatrial node region to the right of the superior vena cava in a counterclockwise direction (type $\mathrm{R} 2 b)$.

L1 originating in the circumflex branch of the left coronary artery with a route medial to the right auricle and

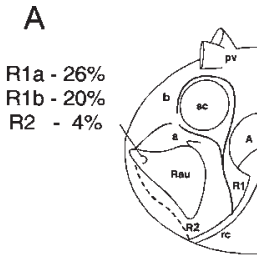

B

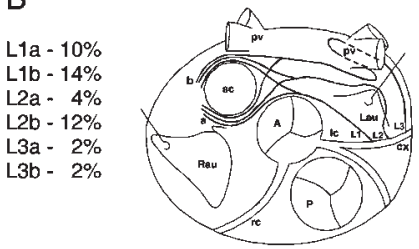

C

R1a and $L 1 b-2 \%$

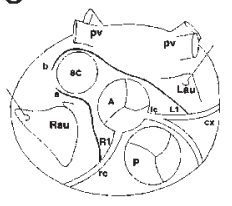

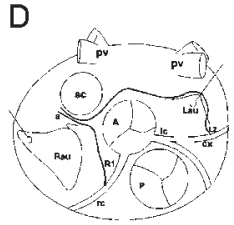

R1a and L2a - $2 \%$
E

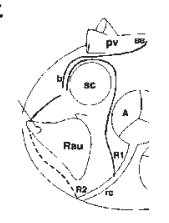

$\mathrm{R} 1 \mathrm{~b}, \mathrm{R} 2$ and $\mathrm{BB}-2 \%$
Figure 1 - Schematic representation of the route types of the sinuatrial node branch (NB) and its frequency. A. Types of the right side. B. Types of the left side. C, D. With 2 NB, 2 types, respectively: R1 $a$, L1 $b$ and R1 $a, \mathrm{~L} 2 a$. E. With 3 NB: 1 type R1a, other type R2 and the third branch probably originated from the bronchial branch of the thoracic aorta

subdivided into L1 $a$ and L1 $b$ (Figure 3), according to its clockwise or counterclockwise route, respectively, at the base of the superior vena cava.

L2 originating in the circumflex branch of the left coronary artery with a route on the left pulmonary surface of the heart posterior to the left auricle and subdivided into L $2 a$ and L $2 b$, according to its clockwise or counterclockwise route, respectively, at the base of the superior vena cava.

L3 originating in the circumflex branch of the left coronary artery with a route that traversed parallel to it, up to the posterior surface of the left atrium, where it described a convex curve to the right, passing inferiorly the left inferior pulmonary vein end and traversing the atrial ceiling to reach the sinuatrial region. This type assumed the

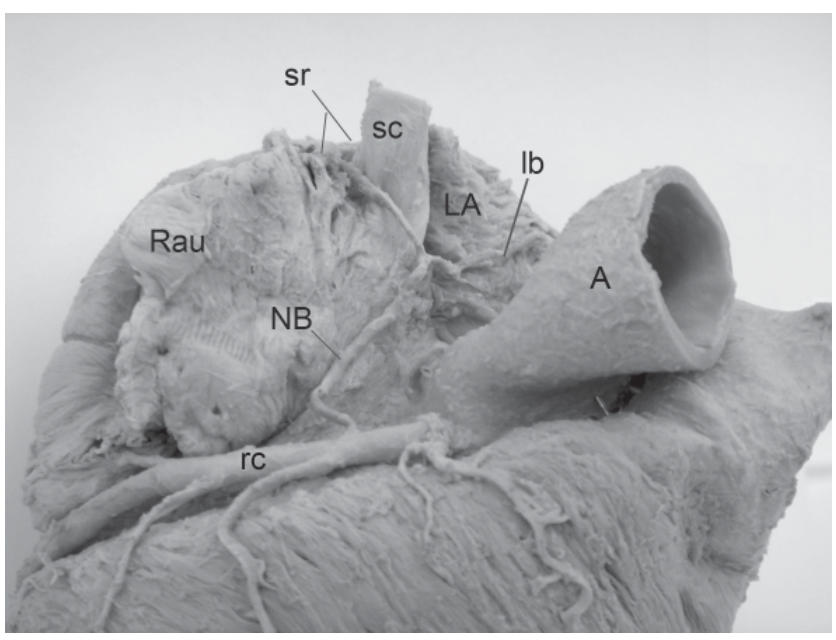

Figure 2 - The sinuatrial nodal branch (NB) is type R1a 


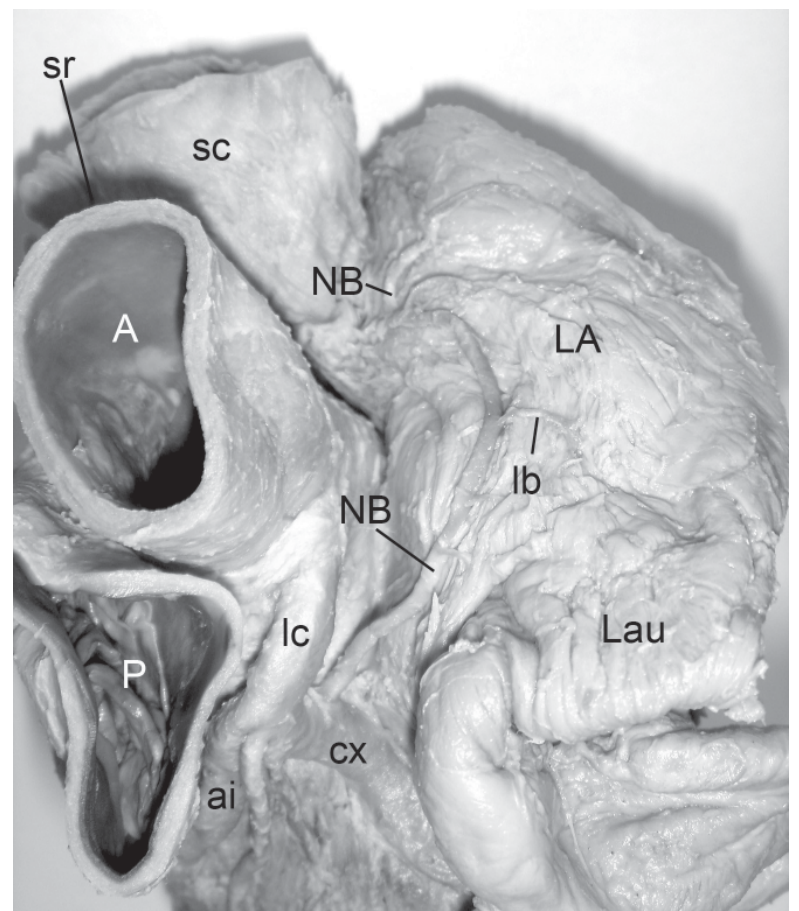

Figure 3 - The sinuatrial nodal branch (NB) is type L1 $b$

form of an "S" in its route, from its origin to the sinuatrial region and could be subdivided into L3a (Figure 4) and L3b, according to its clockwise or counterclockwise route, respectively, at the base of the superior vena cava. For type $\mathrm{R}$, the distance between the right aortic sinus and the origin of the SANB in the right coronary artery was measured. For type L, 2 distances were measured: left 1 (Dist L 1), between the left aortic sinus and the bifurcation of the left coronary artery and left 2 (Dist L 2), between this bifurcation and origin of the SANB in the circumflex branch of the left coronary artery.

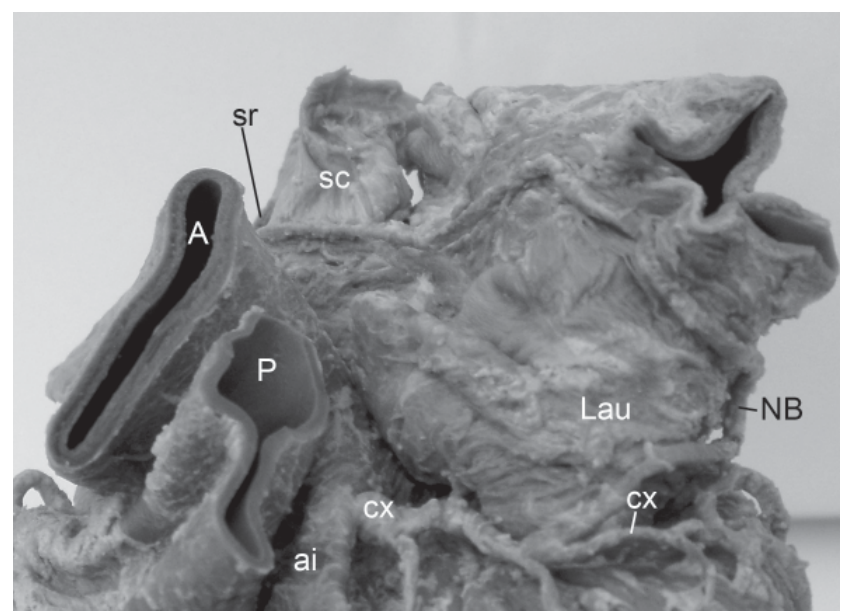

Figure 4 - The sinuatrial nodal branch (NB) is type L3 $a$ and describes a route in " $\mathrm{S}$ " form
A Mitutoyo digital pachymeter was used for the measurements in millimetric units with 1-decimal point approximations. The values were reported as minimum, maximum, and mean \pm SD. A schematic representation of each heart was made, and some were photographed.

\section{RESULTS}

Table 1 shows the frequency, number of branches, origin, diameter, length, distances from the origin to the aortic sinus, and the presence or absence of ring formation at the base of the superior vena cava.

In 47/50 (94\%) cases, a single SANB was found that originated from the right coronary artery in 25/47 of cases and was oriented as follows: $21 / 25$ cases in the anterior segment and in 4/25 cases lateral to this artery. In 22/47 cases, a single SANB was found that originated from the circumflex branch of the left coronary artery, oriented as follows: $17 / 22$ cases in the anterior segment and 5/22 cases in the lateral segment of this branch.

In 2/50 cases (4\%), 2 branches were found originating from the anterior segment, one from the right coronary artery and the other from the circumflex branch of the left coronary artery. In 1/50 cases (2\%), 3 branches were found; 1 branch originated in the anterior segment of the right coronary artery, 1 originated in the lateral segment of the right coronary artery, and 1 was sectioned during the heart removal procedure at the ceiling level of the left atrium and probably originated from the bronchial artery.

In $3 / 50(6 \%)$ cases, all with a single SANB, with $2 / 3$ cases being type $\mathrm{L} 1 b$ and $1 / 3$ type $\mathrm{L} 1 a$, the SANB presented a submerged segment in the interatrial septum along its route; after traversing the left atrial ceiling, it submerged in the septum, it became visible on the surface when reaching the sinuatrial node region.

A ring formation around the base of the superior vena cava was observed in $14 / 47$ cases with 1 SANB, of which 8/14 cases were incomplete and 6/14 cases were complete, and in 1 case with several SANB (Table 1).

In $31 / 47$ cases with a single $\mathrm{SANB}$, the branch reached the node region to the right of the vena cava (type $a, 21 / 31$ and type $b, 10 / 31)$, prior to descending $(25 / 31)$ or not descending $(6 / 31)$ on the terminal sulcus. In 16/47 type $b$ cases, the SANB ascended along on the terminal sulcus to the node region. In 1/50 cases with 2 type $a$ branches, both reached the node region to the right of the vena cava, where one branch descended along on the terminal sulcus and the other did not. In 1/50 cases with 2 branches, the type $a$ branch did not descend along on the terminal sulcus and the type $b$ branch ascended along on the terminal sulcus. In 1/50 cases with 3 branches, 2 originated in the right coronary artery as- 
Ortale JR et al.

Table 1 - Distribution of the frequency, number of branches, origin, diameter, length, distance from origin to aortic sinus, and ring formation at the base of the superior vena cava of the sinuatrial nodal artery branches (SANB)

\begin{tabular}{|c|c|c|c|c|c|c|c|c|c|}
\hline $\begin{array}{l}\text { No.N } \\
\text { branches / } \\
\text { origin origem } \\
1 \text { SANB } \\
1 \text { SNAB }\end{array}$ & $n$ & $\%$ & Do: & Dsr & Leng & Dist $\mathrm{R}$ & Dist L 1 & Dist L 2 & $\begin{array}{c}\text { Complete } \\
\text { Ring }\end{array}$ \\
\hline $\mathrm{o}: \mathrm{rc}$ & 25 & 50 & $\begin{array}{c}1.3-2.5 \\
1.7 \pm 0.3\end{array}$ & $\begin{array}{l}0.8-1.6 \\
1.2 \pm 0.2\end{array}$ & $\begin{array}{c}41.6-105.0 \\
71.4 \pm 14.3\end{array}$ & $\begin{array}{c}1.0-48.6 \\
17.9 \pm 13.6\end{array}$ & - & - & 2 \\
\hline $\mathrm{o}: \mathrm{lc}$ & 22 & 44 & $\begin{array}{l}1.3-2.5 \\
1.8 \pm 0.3\end{array}$ & $\begin{array}{l}0.6-1.4 \\
1.1 \pm 0.2\end{array}$ & $\begin{array}{l}52.5-134.0 \\
95.2 \pm 28.1\end{array}$ & & $\begin{array}{l}2.0-11.0 \\
7.2 \pm 2.6\end{array}$ & $\begin{array}{c}2.6-33.6 \\
13.3 \pm 10.8\end{array}$ & 4 \\
\hline 16 & & & & & & & & & \\
\hline Total & 47 & 94 & $\begin{array}{l}1.3-2.5 \\
1.7 \pm 0.3\end{array}$ & $\begin{array}{l}0.6-1.6 \\
1.1 \pm 0.2\end{array}$ & $\begin{array}{l}41.6-134.0 \\
82.2 \pm 24.4\end{array}$ & $\begin{array}{c}1.0-48.6 \\
17.9 \pm 13.6\end{array}$ & $\begin{array}{l}2.0-11.0 \\
7.2 \pm 2.6\end{array}$ & $\begin{array}{c}2.6-33.6 \\
13.3 \pm 10.8\end{array}$ & 6 \\
\hline $\begin{array}{l}2 \\
\text { SANBSNAB }\end{array}$ & & & & & & & & & \\
\hline $\mathrm{o}: \mathrm{rc}$ and $\mathrm{lc}$ & 2 & 4 & $\begin{array}{l}1.4-2.0 \\
1.9 \pm 0.3\end{array}$ & $\begin{array}{l}0.6-1.3 \\
1.0 \pm 0.3\end{array}$ & $\begin{array}{l}40.1-98.5 \\
64.7 \pm 29.0\end{array}$ & $\begin{array}{l}19.6-21.2 \\
20.4 \pm 1.1\end{array}$ & $\begin{array}{l}6.0-7.2 \\
6.6 \pm 0.8\end{array}$ & $\begin{array}{c}7.6-12.3 \\
10.0 \pm 3.3\end{array}$ & - \\
\hline $\begin{array}{l}3 \\
\text { SANBSNAB }\end{array}$ & & & & & & & & & \\
\hline $\mathrm{o}: \mathrm{rc}$ and $\mathrm{BB}^{*}$ & 1 & 2 & 1.2 & $1 ., 1$ & $85 ., 3$ & $19 ., 9$ & - & - & - \\
\hline Total & 50 & 100 & $\begin{array}{l}1.1-2.5 \\
1.7 \pm 0.3\end{array}$ & $\begin{array}{c}0.6-1.6 \\
1.1 \pm 0.28\end{array}$ & $\begin{array}{c}40.1-134.0 \\
1.3 \pm 24.8\end{array}$ & $\begin{array}{c}1.0-48.6 \\
20.3 \pm 14.7\end{array}$ & $\begin{array}{l}2.0-11.0 \\
7.1 \pm 2.5\end{array}$ & $\begin{array}{c}2.6-33.6 \\
13.0 \pm 10.4\end{array}$ & 6 \\
\hline
\end{tabular}

SNAB = sinuatrial node branch; o: = origin; Do: = diameter at origin; Dsr = diameter in sinuatrial nodal region; Leng = length; Dist $\mathrm{R}=$ distance from ANBSNAB origin in right coronary artery to right aortic sinus; Dist L $1=$ distance from bifurcation of the left coronary artery to the left aortic sinus; Dist $\mathrm{L} 2=$ distance from SNAB origin in circumflex branch to the point of bifurcation of the left coronary artery. rc $=$ right coronary artery; lc = left coronary artery; $\mathrm{BB}^{*}=$ sinuatrial node branch, which was sectioned, probably originating from the bronchial branch of the thoracic aorta and measured only Dsr.

Table 2 - Distribution of number, diameter, and territory of irrigation of the collateral branches of the sinuatrial nodal artery (SANB)

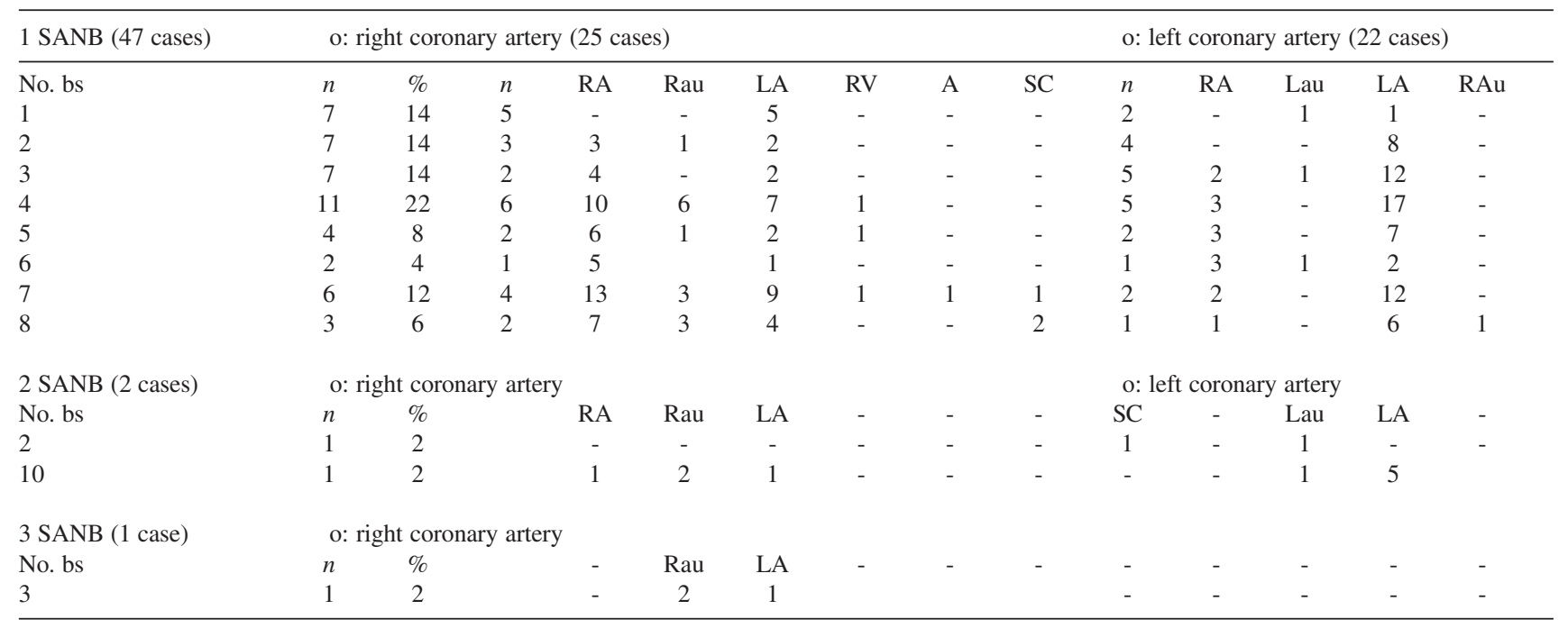

No. $\mathrm{bs}=$ number of collateral branches of the SANB; $\mathrm{o}=$ origin; $\mathrm{R}+\mathrm{L}=$ right and left side; $\mathrm{RA}=$ right atrium; Rau $=$ right auricle; $\mathrm{LA}=$ left atrium; $\mathrm{RV}=$ right ventricle; $\mathrm{A}=$ aorta; $\mathrm{SC}=$ superior vena cava; $\mathrm{Lau}=$ left auricle.

cending along on the terminal sulcus, while the third probably originated in the bronchial branch of the thoracic aorta, descending from the node to the terminal sulcus.

The SANB provided up to 10 collateral branches, where those originating from the right coronary artery emitted collateral vessels to the right atrium, right auricle, right ventricle aorta, left atrium, and/or superior vena cava, while the SANB originating from the left coronary artery emitted collateral vessels to the left atrium, left auricle, right atrium, and/or right auricle (Table 2). The mean \pm SD of 
the diameters of the collateral branches were as follows: in hearts with $1 \mathrm{SANB}, 0.9 \pm 0.2 \mathrm{~mm}$ (range, 0.5-1.6 mm); with $2 \mathrm{SANB}, 0.8 \pm 0.10$ (range, 0.5-1.0 mm); with 3 SANB, $0.6 \pm 0.1 \mathrm{~mm}$ (range, $0.5-0.7 \mathrm{~mm}$ ); and for the 50 hearts, $0.9 \pm 0.2 \mathrm{~mm}$ (range, 0.5-1.6 mm).

\section{DISCUSSION}

The sinuatrial nodal branch of the coronary artery (SANB) corresponds to the eponym "branch of the KeithFlack node," attributed by Crainicianu. ${ }^{16}$ The SANB was the atrial branch with the largest diameter found in the study, except in $4 \%$ of the cases, in which the SANB was collateral to the intermediate atrial branch, which had a slightly larger diameter. The branches for the sinuatrial and atrioventricular nodes, together with the intermediate atrial branch, were the only atrial branches highlighted by the Federative Committee on Anatomical Terminology, ${ }^{21}$ probably due to their functional importance and constancy.

We agree with the authors referred to in Table 3, in that the SANB predominately originates from the right coronary artery, followed in frequency by the circumflex branch of the left coronary artery.

In reference to the number of branches in the sinuatrial node, the results presented are intermediate to those obtained by several authors, $3,4,8,16,18$ who found 2 branches in percentages equal to or less than $11 \%$, one originating from the right coronary artery and the other from the circum- flex branch of the left coronary artery Table 3). In comparison with the present results, it is probable that the higher frequencies shown for the presence of 2 branches of the sinuatrial node reported by Futami et $\mathrm{al}^{10}(23 \%)$ and Kawashima and Sasaki ${ }^{11}(50 \%)$ are anatomical variations associated with a particular ethnic group-Brazilians, of European and African descendent, on the one hand and Japanese on the other. Regarding the frequency of 3 branches, our findings $(2 \%)$ are similar to those of Kawashima and Sasaki ${ }^{11}$ (3.8\%); these authors stated that the greater the number of branches and routes, the greater the possibility of collateral circulation in case of SANB section or obstruction. We agree with these authors ${ }^{11}$ that the sinuatrial branch is situated within the nodal mass. In one case in which 3 branches were found, 2 branches originated from the right coronary artery and the third probably originated from the bronchial artery. This latter branch, due to its extracardiac origin, had been sectioned in the heart removal procedure. This extracardiac origin was first described by Géraudel ${ }^{15}$ and was found as a second branch in $7 \%$ of cases by Hadziselimovic. ${ }^{17}$

With regard to the point of origin of the SANB, it was predominantly in the anterior segment and, in case percentages equal to or less than $10 \%$, in the lateral segment, whether from the right coronary artery or circumflex branch of the left coronary artery; our results are in agreement with those of Romhilt and Hackel ${ }^{3}$ and Hutchinson. ${ }^{13}$ No branch origin was found in the posterior segment of the circum-

Table 3 - Comparison of frequencies of origin and branch numbers of sinuatrial nodal artery branches (SANB) reported by various authors

\begin{tabular}{|c|c|c|c|c|c|c|c|c|}
\hline \multirow[t]{3}{*}{ Author(s) } & \multicolumn{4}{|c|}{1 branch } & \multicolumn{2}{|c|}{2 branches } & \multicolumn{2}{|c|}{3 branches } \\
\hline & $\mathrm{rc}$ & $\mathrm{cx} /$ & lc & $\mathrm{bb}$ & $\mathrm{rc}+\mathrm{cx}$ & $\mathrm{cx} / \mathrm{bb} / \mathrm{rc}$ & $2 \mathrm{rc}+$ & $\mathrm{rc}+$ \\
\hline & $(\%)$ & $(\%)$ & $(\%)$ & & $(\%)$ & $(\%)$ & $1 \mathrm{bb}(\%)$ & $\mathrm{bb}(\%)$ \\
\hline Crainicianu (1922) ${ }^{10}$ & 68.0 & 25.0 & - & - & 7.0 & - & - & - \\
\hline Géraudel (1925) ${ }^{15}$ & + & + & - & + & - & - & - & - \\
\hline Campbell (1929) ${ }^{1}$ & 52.6 & 13.7 & 33.7 & - & - & - & - & - \\
\hline James $(1961)^{2}$ & 55.0 & 45.0 & - & - & - & - & - & - \\
\hline Romhilt et al (1968) ${ }^{3}$ & 60.8 & 37.6 & - & - & 1.6 & - & - & - \\
\hline Kennel and Titus (1972) ${ }^{12}$ & 65.0 & 35.0 & - & - & - & - & - & - \\
\hline Hadziselimovic (1978) ${ }^{17}$ & 60.0 & 40.0 & - & - & - & $15 / 12 / 7 *$ & - & - \\
\hline Hutchinson (1978) ${ }^{13}$ & 65.0 & 35.0 & - & - & - & - & - & - \\
\hline Nerantzis and Avgoustakis (1980) ${ }^{4}$ & 62.0 & 37.0 & - & - & 1.0 & - & - & - \\
\hline Bokeriya et al (1984) ${ }^{5}$ & 61.4 & 28.6 & 10.0 & - & - & - & - & - \\
\hline Busquet et al (1984) ${ }^{18}$ & 66.0 & 30.0 & - & - & 4.0 & - & - & - \\
\hline Henriquez et al (1984) ${ }^{7}$ & 67.5 & 32.5 & - & - & - & - & - & - \\
\hline Caetano et al (1995) ${ }^{14}$ & 58.0 & 30.0 & 12.0 & - & - & - & - & - \\
\hline Sow et al $(1996)^{8}$ & 64.5 & 24.4 & - & & 11.1 & - & - & - \\
\hline Jatene et al (1999) ${ }^{9}$ & 63.3 & 36.7 & - & - & - & - & - & - \\
\hline Futami et al (2003) ${ }^{10}$ & 73.4 & 3.3 & & & 23.3 & - & - & - \\
\hline Kawashima and Sazaki $(2003)^{11}$ & 32.0 & 14.2 & - & - & 50.0 & - & - & 3.8 \\
\hline Present study (2006) & 50.0 & 44.0 & - & - & 4.0 & - & 2.0 & - \\
\hline
\end{tabular}

$\mathrm{rc}=$ right coronary artery; $\mathrm{lc}=$ trunk of left coronary artery; $\mathrm{cx}$, circumflex branch of left coronary artery; bb = bronchial branch of the thoracic aorta

$*$ The second branch originated from the circumflex branch of the left coronary artery, the bronchial artery, or the right coronary artery in $15 \%, 12 \%$, and

$7 \%$ of cases, respectively 
flex branch, as has been reported in $7.5 \%$ of cases, ${ }^{6}$ nor directly in the right aortic sinus, reported in $1.7 \%$ of cases. ${ }^{12}$

The mean diameter of the SANB, measured at the point of origin, was $1.7 \mathrm{~mm}$, and measured within the node was $1.1 \mathrm{~mm}$, both slightly larger than those reported by Kennel and Titus ${ }^{12}(1.1 \mathrm{~mm}$ and $0.7 \mathrm{~mm})$. The branch length varied from 40.1 to $134 \mathrm{~mm}$, values that were practically equal to those reported by Nerantzis and Avgoustakis (50$135 \mathrm{~mm}){ }^{4}$ The distance between the ostium of the right coronary sinus and the SANB origin was practically the same as that reported by Henríquez et al, ${ }^{7}$ while the distance between the origin of the circumflex branch and the SANB origin was slightly less than that described by those authors. ${ }^{7}$ Considering both sides, the degree of variation in the distance between the SANB origin and the ostia of the coronary sinus was greater than that reported by Nerantzis and Avgoustakis. ${ }^{4}$

In agreement with the results of several authors, ${ }^{3,6,9,13}$ the most frequently observed types on the right side were the medial route to the base of the right auricle, followed by the posterior route to the right atrium, the latter found in no more than $10 \%$ of cases. ${ }^{9}$ On the left side, in decreasing order, the routes were medial to the auricle, posterior to the base of the left auricle, and posterior to the left atrium. These last two were considered to be the same by Jatene et al. ${ }^{9}$

In $8 \%$ of cases, a percentage equal to or greater than that reported by a number of authors, ${ }^{4,12,22}$ we observed that the SANB formed an "S", originating in the anterior or lateral segment and running parallel to the circumflex branch of the left coronary artery, describing a curve on the lateral surface (type E2) or on the posterior surface (type E3) of the left atrium, curving again under the left pulmonary vein to arrive at the atrial ceiling and the sinuatrial node.

In agreement with the results of Crainicianu, ${ }^{16}$ the SANB, whether originating in the right coronary artery or the circumflex branch of the left coronary artery, generally had a submerged route in the myocardium or sometimes in the interatrial septum. However, in some cases, the SANB was more than $2.0 \mathrm{~mm}$ in diameter, following a surface route to the node region, possibly presenting collateral branches.

Regarding the ring formation around the base of the superior vena cava by the SANB, several authors ${ }^{13,15,16}$ have reported that in a small number of cases, the SANB divides into branches that circle the base of the superior vena cava, thus forming a ring. This ring was complete, with the branch of greatest diameter following a counterclockwise route, in $12 \%$ of the cases observed in this study, a smaller percentage than the $16 \%$ reported by Anderson et al. ${ }^{22}$ The ring was incomplete in $18 \%$ of the cases observed in the current work, all with an counterclockwise route, except in 1 case, in agreement with Kennel and Titus. ${ }^{12}$ The ring was absent in $70 \%$ of the cases observed in this study, and the route traversed the node in a clockwise $(44 \%)$ or counterclockwise $(26 \%)$ direction. Thus, considering the total number of cases, the SANB showed a counterclockwise route in the majority of cases (54\%), in agreement with Kennel and Titus ${ }^{12}$ and Anderson et al. ${ }^{22}$

In $6 \%$ of cases, a collateral branch of the SANB to the right ventricle was observed, such that in 1 of these cases, the branch provided was atrioventricular. ${ }^{23}$

The following conclusions were drawn: a) in $94 \%$ of cases only a single SANB was observed, originating from the right coronary artery $(50 \%)$ and the left coronary artery (44\%); in $4 \%$ of cases, 2 SANB were found, one on each side; in $2 \%$ of cases, 3 SANB were observed with 2 branches originating from the right coronary artery and a third probably from the bronchial artery. b) The length of the SANB originating from the left side was longer than that from the right. c) A predominance for the medial to auricle route occurred, whether the SANB originated from the left or right side. d) In $8 \%$ of cases, the SANB originating from the left presented the form of an "S". e) At the base of the superior vena cava, the SANB presented a counterclockwise route in $54 \%$ of cases and a clockwise route in $46 \%$, and in $30 \%$ of cases it formed a ring around the vein. f) In all cases, the SANB provided collateral branches to the atrium and/or the auricle of the same side as its origin and/or the opposite side. g) The frequency of the presence of 2 SANB was less in the Brazilians of European and African descent $(4 \%)$ in this study than in those of Japanese decent $(50 \%)$ reported in a previous study, ${ }^{11}$ which is probably an example of anatomical variations associated with ethnic origin.

\section{RESUMO}

Ortale JR, Paganoti C de F, Marchiori GF. As variações de número, origem e trajeto do ramo do nó sinoatrial em corações humanos. Clinics. 2006;61(6):551-8.
OBJETIVO: Analisar as variações anatômicas do ramo do nó sinoatrial, principalmente quanto ao número, visto que a escola japonesa relatou a presença de dois ramos em até 
$50 \%$ dos casos, fato que permitiria a compensação, em caso de oclusão ou secção de um dos ramos.

MÉTODOS: O ramo do nó sinoatrial foi dissecado com o auxílio de lente de aumento com pala Normo Health, de 3,0 graus, em 50 corações fixados em solução de formol.

RESULTADOS: Em 94\% dos casos, havia um ramo do nó sinoatrial, classificado em dois tipos do lado direito: D1 (46\%) - ramo do nó sinoatrial situado medialmente à aurícula direita; D2 (4\%) - ramo do nó sinoatrial na face posterior do átrio direito; e três tipos do lado esquerdo: E1 (24\%) - ramo do nó sinoatrial medial à aurícula esquerda; E2 (16\%) - posterior à aurícula esquerda; E3 (4\%) - na face posterior do átrio esquerdo. Cada tipo, exceto D2, era subdividido em a ou b, conforme o sentido do RNSA fosse, respectivamente horário ou anti-horário ao redor da base da veia cava superior. Em 4\% dos casos, havia dois ramos do nó sinoatrial, originados de ambas as artérias coronárias. Em $2 \%$ dos casos, havia três ramos do nó sinoatrial originados, dois da artéria coronária direita e o terceiro, provavelmente de artéria brônquica. Em 30\% dos casos, o ramo do nó sinoatrial formava um anel ao redor da base da veia cava superior. Em todos os casos, o ramo do nó sinoatrial forneceu ramos colaterais para o átrio e/ou a aurícula do mesmo lado e/ou do lado oposto à sua origem.

CONCLUSÃO: A baixa freqüência de dois ramos do nó sinoatrial em indivíduos brasileiros, comparada à alta encontrada em japoneses, provavelmente seja variação associada com as diferentes origens étnicas.

UNITERMOS: Artérias. Circulação coronária. Átrio. Sistema de condução do coração. Anatomia macroscópica.

\section{REFERENCES}

1. Campbell JS. Stereoscopic radiography of the coronary system. Quart J Med. 1929;22:247-68.

2. James TN. Anatomy of the human sinus node. Anat Rec. 1961;141:109-16.

3. Romhilt DW, Hackel DB. Origin of blood supply to sinoauricular and atrioventricular node. Am Heart J. 1968;75:279-80.

4. Nerantzis C, Avgoustakis D. An S-shaped atrial artery supplying the sinus node area; an anatomical study. Chest. 1980;78:274-8.

5. Bokeriya, LA, Mikhailin SI, Revishvili AS. Anatomical variants of sinoatrial and atrioventricular node arteries. Cor Vasa. 1984;26: 220-8.

6. Krupa U. The sinuatrial nodal artery in the human heart. Folia Morphol (Warsz). 1993;52:29-37.

7. Henriquez J., Olave E, Matamala F. Ramas arteriales de los nodos del sistema de conducción cardíaca. An Anat Nor. 1989;7:45-49.

8. Sow ML, Ndoye JM, Lô A. The artery of the sinuatrial node: anatomic considerations based on 45 injection-dissections of the heart. Surg Radiol Anat. 1996;18:103-9.
9. Jatene MB, Hervoso CM, Terra RM, Guimarães MH, Monteiro R, Jatene $\mathrm{FB}$, et al. Importância da anatomia da circulação coronária atrial na operação de Cox para controle da fibrilação atrial. Rev Bras Cir Cardiovasc. 1999;14:1-11.

10. Futami C, Tanuma K, Tanuma Y, Saito T. The arterial blood supply of the conducting system in normal human hearts. Surg Radiol Anat. 2003;25:42-9.

11. Kawashima T, Sasaki H. The morphological significance of the human sinuatrial nodal branch (artery). Heart Vessels. 2003;18:213-9.

12. Kennel AJ, Titus JL. The vasculature of the human sinus node. Mayo Clin Proc. 1972;47:556-61.

13. Hutchinson ME. A study of the atrial arteries in man. J Anat. 1978;125:39-64.

14. Caetano AG, Lopes AC, DiDio LA, Prates JC. Análise crítica da importância clínica e cirúrgica das variações da origem da artéria do nó sinoatrial do coração humano. Rev Ass Med Brasil. 1995;41:94-102.

15. Géraudel E. L'artère de l'atrio-necteur. Presse Méd. 1925;33:1283-6. 
16. Crainicianu A. Anatomische Studien über die Coronararterien und experimentelle Untersuchungen über ihre Durchgängigkeit. Virchows Archiv. 1922;238:1-75.

17. Hadziselimovic H. Vascularization of the conducting system in the human heart. Acta Anat. 1978;102:105-10.

18. Busquet J, Fontan F, Anderson RH, Ho SY, Davies MJ. The surgical significance of the atrial branches of the coronary arteries. Int J Cardiol. 1984;6:223-34

19. Ortale JR, Keiralla LB, Sacilotto L. The posterior ventricular branches of the coronary arteries in the human heart. Arq Bras Cardiol. 2004;82:468-72.
20. Ortale JR, Meciano Filho J, Paccola AF, Leal JG, Sacaranari CA. Anatomy of the lateral, diagonal and anterosuperior arterial branches of the left ventricle of the human heart. Braz J Cardiovasc Surg. 2005;20:149-58.

21. F.C.A.T. Federative Committee on Anatomical Terminology. International Anatomical Terminology. Stuttgart, Thieme, 1998.

22. Anderson KR, Ho SY, Anderson RH. Location and vascular supply of sinus node in human heart. Br Heart J, 1979;41:28-32.

23. DiDio JA. The atrioventricular branches of the human coronary arteries. J Morphol. 1967;123:397-404. 